\title{
Aplikasi Absensi Jemaat Berbasis Android
}

\author{
Billy B. Sumolang ${ }^{1)}$, Steven R. Sentinuwo ${ }^{2)}$, Xaverius B. N. Najoan ${ }^{3)}$ \\ Program Studi Teknik Informatika, Fakultas Teknik, Universitas Sam Ratulangi \\ billysumolang@gmail.com, steven@unsrat.ac.id, xnajoan@unsrat.ac.id
}

\begin{abstract}
Abstrak-Teknologi telah berkembang terus-menerus dalam banyak aspek kehidupan manusia, salah satunya ada dalam praktek keagamaan. Selama beberapa tahun terakhir, pemanfaatan teknologi di lingkungan Gereja juga berkembang. Teknologi yang sangat popular saat ini adalah Smartphone (ponsel pintar) Berbasis Android. Dengan adanya teknologi ini, memudahkan manusia dalam mengakses informasi dan mengolah informasi yang diperlukan. Penelitian ini bertujuan untuk membuat aplikasi android yang dapat membantu mempermudah pelsus melakukan absensi dalam hal ini tingkat keaktifan anggota jemaat dalam peribadatan serta memudahkan pelaporan persembahan dalam bentuk aplikasi yang terpasang di ponsel pintar khususnya android. Metodologi yang digunakan untuk pembuatan aplikasi ini adalah metode Rapid Application Development (RAD). Metode ini mempunyai empat tahapan kerja yaitu analisis persyaratan, analisis modeling, desain modeling dan konstruksi. Presensi anggota jemaat dan pelaporan persembahan dapat di aplikasikan dengan menggunakan android yang dijalankan pada ponsel pintar pada setiap peribadatan di tingkat kolom.
\end{abstract}

Kata Kunci : Aplikasi, Absensi, Android, Rapid Application Development.

Abstrak-Technology has developed continuously in many aspects of human life, one of which is in religious practice. Over the past few years, the use of technology in the Church has also developed. The technology that is very popular today is smartphones (smart phones) based on Android. With this technology, it is easier for humans to access information and process the information needed. This study aims to create an android application that can help facilitate pelsus absenteeism in this case the level of active members of the congregation in worship and facilitate reporting of offerings in the form of applications installed on smart phones, especially android. The methodology used to make this application is the Rapid Application Development method (RAD). This method has four working stages, namely requirements analysis, modeling analysis, modeling and construction design. Membership presences and reporting of offerings can be applied using android that is run on smart phones at every worship at the column level.

Keywords: Application, Attendance, Android, Rapid Application Development.

\section{PENDAHULUAN}

Teknologi telah berkembang terus-menerus dalam banyak aspek kehidupan manusia, salah satunya ada dalam praktek keagamaan. Selama beberapa tahun terakhir, pemanfaatan teknologi di lingkungan Gereja juga berkembang. Saat ini, hampir semua operasional sudah di dukung dengan aplikasi berbasis teknologi. Hal ini dikarenakan perkembangan teknologi yang semakin hari semakin pesat, sehingga memunculkan banyak inovasi baru dari teknologi. Teknologi yang sangat popular saat ini adalah Smartphone (ponsel pintar) Berbasis Android. Dengan adanya teknologi ini, Memudahkan manusia dalam mengakses informasi dan mengolah informasi yang diperlukan. Melalui teknologi kebutuhan jemaat, dari segi aktifitas keagamaan dapat terakomodasi.

Pada era modern ini tidak menutup kemungkinan aplikasi pada ponsel pintar dapat digunakan sebagai media pendataan tingkat kehadiran anggota jemaat di peribadatan kolom, dalam hal ini Gereja. Dikarenakan smartphone dapat dikatakan sebagai kebutuhan sekunder untuk setiap orang karena fungsinya yang jauh lebih praktis dan efisien serta kemajuan teknologi dapat digunakan sesuai peruntukannya.

Peneliti tertarik untuk mengembangkan suatu penelitian dalam bentuk aplikasi android yang dapat membantu mempermudah pelsus dalam hal mencatat keaktifan anggota jemaat dalam peribadatan serta memudahkan pelaporan persembahan dalam bentuk aplikasi yang terpasang di ponsel pintar khususnya android.

Berdasarkan latar belakang yang telah penulis uraikan diatas maka penulis dalam pembuatan aplikasi ini mengambil judul "Aplikasi Absensi Jemaat Berbasis Android".

\section{A. Aplikasi}

Aplikasi adalah suatu sub kelas perangkat lunak computer yang memanfaatkan kemampuan komputer langsung untuk melakukan suatu tugas yang diinginkan penguna. Biasanya dibandingkan dengan perangkat lunak system yang mengintegrasikan berbagai kemampuan komputer, tapi tidak secara langsung menerapkan kemampuan tersebut untuk mengerjakan suatu tugas yang menguntungkan penguna. ${ }^{[1]}$

\section{B. Absensi}

Absensi adalah daftar kehadiran pegawai/siswa, yang berisi jam datang, jam pulang, serta alasan/keterangan kehadiran pegawai. Absensi juga merupakan suatu daftar pendataan kehadiran seseorang dari suatu aktifitas di sebuah institusi yang diatur dan disusun sedemikian rupa sehingga dapat digunakan sewaktu -waktu oleh pihak yang berkepentingan. Dimana data dari pegawai yang tidak hadir akan tercatat di daftar kepegawaian dan dapat di periksa kapan saja oleh pihak instansi tersebut. Dalam bahasa inggris, pemakaian kata absen sering digunakan sebagai istilah List of Absent, yang berarti seseorang yang tidak hadir dalam suatu pertemuan sedangkan pemakaian kata kehadiran sering digunakan sebagai istilah List of Presence atau List of Participants. $^{[2]}$ 


\section{Android}

Android adalah sebuah sistem operasi untuk perangkat mobile berbasis linux yang mencakup sistem operasi, middleware dan aplikasi. Android menyediakan platform terbuka bagi para pengembang untuk menciptakan aplikasi mereka. Awalnya, Google Inc. membeli Android Inc. yang merupakan pendatang baru yang membuat piranti lunak untuk ponsel atau smartphone. Kemudian untuk mengembangkan Android dibentuklah Open Handset Alliance (OHA), konsorium dari 34 perusahaan peranti keras, peranti lunak, dan telekomunikasi termasuk Google, HTC, Intel, Motorola, Qualcomm, TMobile dan Nvidia. ${ }^{[3]}$

\section{Android Studio}

Android Studio adalah sebuah lingkungan pengembangan terpadu IDE (Integrated development Environment) untuk mengembangkan pada platform android. Android Studio merupakan software yang dapat meningkatkan produktivitas dan mempermudah pekerjaan dalam membuat aplikasi android. Android studio menyediakan berbagai fitur dan peralatan yang sangat dibutuhkan oleh para developer (pengembang) dengan pemograman java. Android studio di perkenalkan oleh google secara resmi pada tahun 2013. Dalam penelitian ini penulis menggunakan bahasa java sebagai bahasa pemograman. ${ }^{[4]}$

\section{E. Gereja Masehi Injili di Minahasa (GMIM)}

GMIM merupakan salah satu gereja terbesar di Indonesia yang beraliran Calvinisme. GMIM didirikan di Minahasa, Sulawesi Utara pada tahun 1934 setelah dipisahkan dari Gereja induknya, "Indische Kerk" (yang sekarang menjadi Gereja Protestan di Indonesia/GPI) dan pada tanggal 30 September 1934 GMIM dinyatakan sebagai Gereja mandiri. Tanggal ini diperingati sebagai hari jadi GMIM. ${ }^{[5]}$

\section{1) GMIM Zaitun Karombasan}

Gereja GMIM Zaitun adalah sebuah jemaat hasil pemekaran dari jemaat Gereja GMIM Perjanjian Pakowa (GMIM Syaloom Karombasan). Pada tanggal 27 Juli 1971, diterbitkan keputusan oleh Badan Pekerja Sinode GMIM No. 146 tanggal 27 Juli 1971 dan mulai saat itu Jemaat kanisah Ranotana weru menjadi satu jemaat yang dewasa dan mandiri dalam tugas-tugas pelayanannya menjadi Jemaat Zaitun Ranotana weru.

\section{F. $\quad$ Unified Modeling Language (UML)}

Unified Modeling Language (UML) adalah bahasa standard untuk pembutan sebuah cetak biru untuk membangun sebuah aplikasi, UML berguna untuk memvisualisasikan, menentukan, mengonstruksi, dan mendokumentasikan artifakartifak suatu system. ${ }^{[6]}$

\section{1) Use Case Diagram}

Use case adalah deskripsi fungsi dari sebuah sistem perspektif pengguna. Use case bekerja dengan cara mendeskripsikan tipikal interaksi antara pengguna (user) sebuah sistem dengan sistemnya sendiri melalui sebuah cerita bagaimana sebuah sistem digunakan. Urutan langkah-langkah yang menerangkan antara pengguna dan sistem disebut skenario.
2) Class Diagram

Class diagram menggambarkan struktur statis dari kelas dalam sistem anda dan menggambarkan atribut, operasi dan hubungan antar kelas. Class diagram membantu dalam memvisualisasikan struktur kelas-kelas dari suatu sistem dan merupakan tipe diagram yang paling banyak dipakai. Selama tahap desain, class diagram berperan dalam menangkap struktur dari semua kelas yang membentuk arsitektur sistem yang dibuat.

\section{3) Sequence Diagram}

Sequence diagram menggambarkan interaksi antar objek di dalam dan disekitar sistem (termasuk pengguna, display, dan sebagainya) berupa message yang digambarkan terhadap waktu. Sequence diagram terdiri antar dimensi vertikal (waktu) dan dimensi horizontal (objek-objek yang terkait).

\section{G. Rapid Application Development (RAD)}

Rapid Application Development (RAD) adalah salah satu metode pengembangan suatu sistem informasi dengan waktu yang relatif singkat. Untuk pengembangan suatu sistem informasi yang normal membutuhkan waktu minimal 180 hari, akan tetapi dengan menggunakan metode RAD suatu sistem dapat diselesaikan hanya dalam waktu 30-90 hari. DRAD bisa menghasilkan suatu sistem dengan cepat karena sistem yang dikembangkan dapat memenuhi keinginan dari para pemakai sehingga dapat mengurangi waktu untuk pengembangan ulang setelah tahap implementasialam metode RAD terdapat langkah - langkah yang dibagi dalam empat fase sebagai berikut. ${ }^{[7]}$

\section{1) Fase analisis persyaratan}

Fase ini memiliki tujuan untuk mengidentifikasi layanan, batasan, dan obyektifitas dari sistem dari pengumpulan data yang dilakukan terhadap stakeholder. Selain itu analisis persyaratan juga bertujuan untuk mendefinisikan persyaratan user dan sistem. Hasil akhir dari analisis persyaratan yaitu spesifikasi awal dari persyaratan user dan system.

\section{2) Fase analisis modeling}

Tujuan dari fase analisis modeling adalah menganalisis semua kegiatan dalam arsitektur sistem secara keseluruhan dengan melibatkan identifikasi dan deskripsi abstraksi sistem perangkat lunak secara yang mendasar dan hubunganhubungannya. Selain itu, analisis modeling juga bertujuan untuk meningkatkan pemahaman terhadap permasalahan tanpa mempertimbangkan solusi teknis. Hasil akhir dari analisis modeling yaitu diagram model logis dari sistem yang sedang berjalan, diantaranya use case diagram, activity diagram, class diagram, dan sequence diagram

\section{3) Fase desain modeling}

Tujuan dari fase desain modeling yaitu melakukan perancangan sistem berdasarkan analisis yang telah dilakukan sebelumnya. Tahap analisis dan desain mengalami perulangan hingga diperoleh rancangan sistem yang benar-benar memenuhi kebutuhan. Selain itu, fase 3 ini juga bertujuan untuk memberikan spesifikasi yang jelas dan lengkap kepada programmer dan teknisi. Hasil akhir dari fase ini yaitu basis data, antarmuka, dan spesifikasi desain. 
4) Fase konstruksi

Tujuan dari fase konstruksi adalah untuk menunjukkan platform, hardware dan software yang digunakan serta batasan dalam implementasi, serta menguji performansi prototipe perangkat perangkat lunak yang telah dibangun agar dapat diketahui apakah prototipe tersebut telah sesuai dengan spesifikasi analisis dan perancangan yang telah diidentifikasi sebelumnya. Hasil akhir dari fase konstruksi adalah platform, hardware dan software yang digunakan, serta daftar batasan implementasi, dan rencana pengujian.

\section{H. Pengujian Kotak Hitam (Black Box Testing)}

Pengujian kotak hitam berfokus pada persyaratan fungsional perangkat lunak. Artinya, teknik pengujian kotak hitam memungkinkan untuk membuat beberapa kumpulan kondisi masukan yang sepenuhnya akan melakukan semua kebutuhan fungsional untuk program. ${ }^{[6]}$ Pengujian kotak hitam berupaya untuk menemukan kesalahan dalam kategori berikut:

1) Fungsi yang salah atau hilang.

2) Kesalahan antarmuka.

3) Kesalahan dalam struktur data atau akses basis data eksternal.

4) Kesalahan perilaku atau kinerja.

5) Kesalahan inisialisasi dan penghentian.

\section{METODOLOGI PENELITIAN}

\section{A. Metode Pengumpulan Data}

\section{1) Data Primer}

Sumber data primer diambil berdasarkan data sensus jemaat GMIM zaitun karoweru tahun 2017.

\section{2) Data Sekunder}

Data sekunder merupakan data yang diperoleh dari peneliti sebagai pendukung dalam penelitian ini. Data ini diambil menurut proses studi pustaka yang terkait dengan penelitian dan kemudian dirangkum untuk menjadi sebuah konstribusi penelitian.

\section{3) Teknik Pengambilan Data}

Proses pengambilan data dilakukan secara manual, penulis mengunjungi kantor jemaat dan mengumpulkan informasi yang diperlukan dalam menunjang pembuatan aplikasi yang dimaksud.

\section{a. Observasi}

Observasi atau pengamatan merupakan aktivitas terhadap suatu objek yang dilakukan secara langsung untuk mendapatkan informasi tentang objek penelitian tersebut. Observasi dilakukan untuk memperoleh data dalam menunjang pembuatan aplikasi absensi jemaat berbasis android. b. Study literatur

Studi literatur dilakukan dengan mengumpulkan bukubuku atau jurnal yang berkaitan tentang penelitian yyang diperlukan untuk mendapatkan referensi yang tepat dan akurat sesuai dengan masalah yang diteliti. RAD merupakan proses model perangkat lunak inkremental yang menekankan siklus pengembangan yang singkat.

\section{B. Fase Analisis Persyaratan}

Fase Analisis Persyaratan merupakan proses melakukan pengumpulan data atau bahan dan mengidentifikasi layanan, batasan, dan obyektivitas dari pengumpulan data yang dilakukan. Hasil dari proses ini berupa laporan penelitian dari pengembangan aplikasi, analisis spesifikasi awal, analisis persyaratan user dan sistem, dan informasi fitur pada aplikasi. Dalam proses ini sumber daya yang digunakan yaitu komputer dan handphone dengan koneksi internet, buku literatur dan penelitian.

\section{1) Rencana Kerja}

Aplikasi Absensi Jemaat Berbasis Android digambarkan dalam Work Breakdown Structure (WBS), yang mana di dalam WBS dirancang mengikuti tahapan RAD. Tujuan penelitian ini yaitu membuat Aplikasi Absensi Jemaat berbasis Android dengan empat tahapan kerja yaitu analisis persyaratan, analisis modeling, desain modeling dan konstruksi. Empat tahapan kerja ini terbagi atas enam belas aktivitas yang dapat dilihat pada gambar 1 .

\section{2) Spesifikasi Pengguna}

Langkah ini merupakan langkah mengidentifikasi dan menetapkan kebutuhan-kebutuhan pengguna. Proses absensi dan penginputan jumlah persembahan di tiap peribadatan dilakukan oleh Pelsus dalam hal ini Penatua atau Syamas. Pelsus melakukan absensi dan penginputan jumlah persembahan kedalam aplikasi setelah peribadatan kolom selesai. Ketua BPMJ atau Sekretaris Jemaat dapat melihat hasil dari penginputan data dari setiap kolom.

\section{Fase Analisis Modeling}

Fase analisis modeling yang bertujuan menganalisis semua kegiatan dalam arsitektur sistem secara keseluruhan dengan cara identifikasi dan abstraksi sistem yang mendasar. Proses yang dilakukan dimulai dari mengidentifikasi aktor dan use case dengan merancang aplikasi yang akan dikembangkan, menggambarkan aliran control untuk mengetahui hubungan aktor dan objek, menggambarkan komunikasi antar objek dan aktor, menggambarkan perubahan keadaan suatu objek pada aplikasi kelas tertentu, memodelkan prilaku use case serta objek pada aplikasi dan menggambarkan perubahan suatu objek pada kelas tertentu. Masukan pada tahapan ini yaitu informasi aplikasi pada penelitian sebelumnya, data - data hasil dari tahapan Fase satu Analisis Persyaratan dan metode yang akan digunakan pada fase berikutnya. 


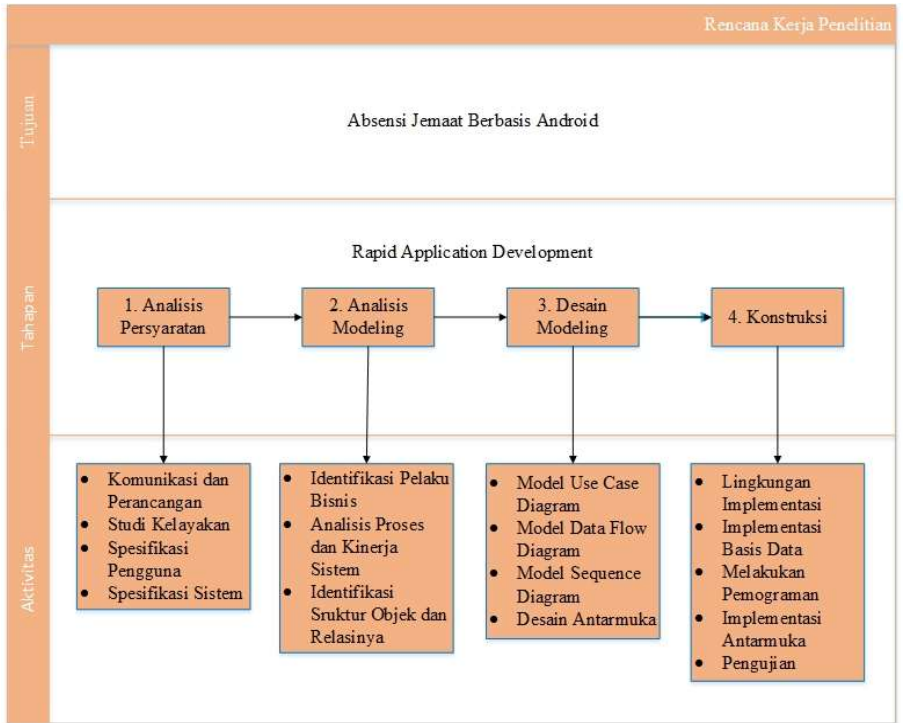

Gambar 1. Rencana Kerja Penelitian

TABEL I. SPESIFIKASI PENGGUNA

\begin{tabular}{|c|c|}
\hline Pengguna & Tugas dan Tanggung Jawab \\
\hline Pelsus & $\begin{array}{l}\text { 1. Melakukan laporan ke aktifan } \\
\text { anggota jemaat. } \\
\text { 2. Menginput jumlah persembahan } \\
\text { ke dalam Aplikasi. }\end{array}$ \\
\hline $\begin{array}{l}\text { Ketua BPMJ atau } \\
\text { Sekretaris Jemaat }\end{array}$ & $\begin{array}{l}\text { 1. Melihat data yang telah diinput. } \\
\text { 2. Mengedit data jemaat. }\end{array}$ \\
\hline
\end{tabular}

TABEL II. DAFTAR AKTOR BESERTA TUGAS DAN TANGGUNG JAWAB

\begin{tabular}{|c|c|}
\hline Aktor & Tugas dan Tanggung Jawab \\
\hline $\begin{array}{l}\text { Admin } \\
\text { (Android }\end{array}$ & $\begin{array}{l}\text { 1. Mengatur database berupa penambahan } \\
\text { data, edit data, dan hapus data }\end{array}$ \\
\hline App $\quad-$ & 2. Menambah username dan password user. \\
\hline $\begin{array}{l}\text { Admin } \\
\text { side) }\end{array}$ & $\begin{array}{l}\text { 3. Merekap data untuk dijadikan bahan } \\
\text { evaluasi }\end{array}$ \\
\hline $\begin{array}{l}\text { User } \\
\text { (Android }\end{array}$ & $\begin{array}{l}\text { 1. Melakukan presensi dalam hal keaktifan } \\
\text { anggota jemaat }\end{array}$ \\
\hline App $\quad-$ & 2. Melakukan pelaporan persembahan \\
\hline $\begin{array}{l}\text { Client } \\
\text { side) }\end{array}$ & 3. Melihat informasi umum seputar Gereja \\
\hline
\end{tabular}

1) Tabel I menunjukkan spesifikasi pengguna yang mempunyai peran dan tanggung jawab yang berbeda-beda antara User dalam hal ini Pelsus Kolom dan Admin.

2) Tabel 2 Proses absensi dan penginputan jumlah persembahan di tiap peribadatan dilakukan oleh Pelsus dalam hal ini Penatua atau Syamas. Pelsus melakukan absensi dan penginputan jumlah persembahan kedalam aplikasi setelah peribadatan kolom selesai. Ketua BPMJ atau Sekretaris Jemaat dapat melihat hasil dari penginputan data dari setiap kolom.

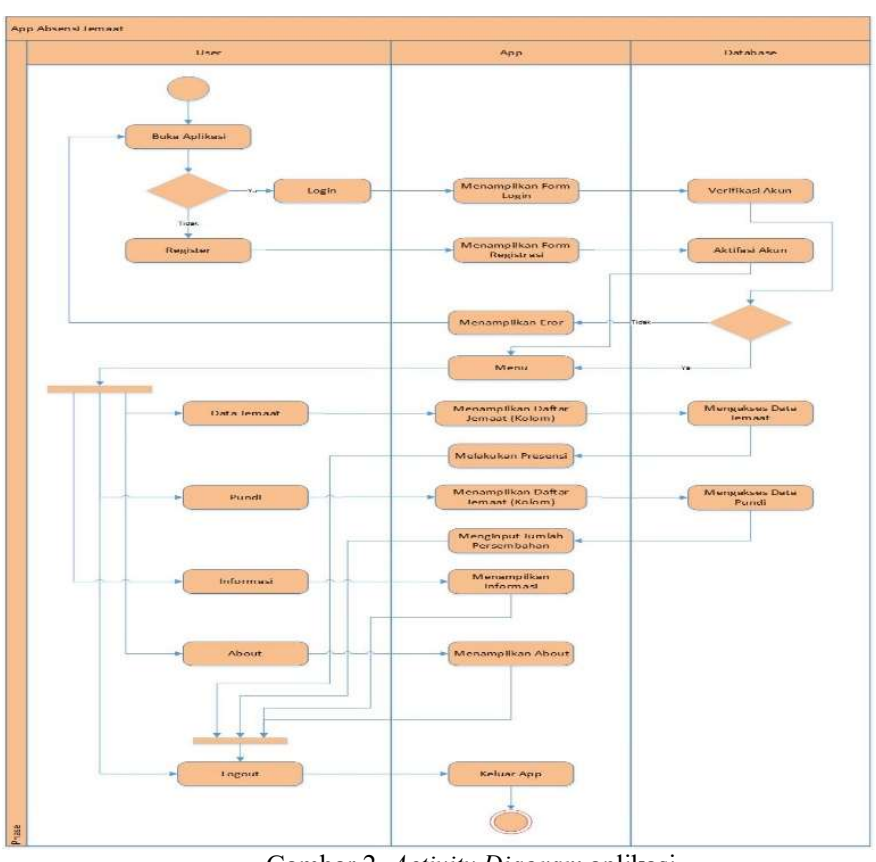

Gambar 2. Activity Diagram aplikasi

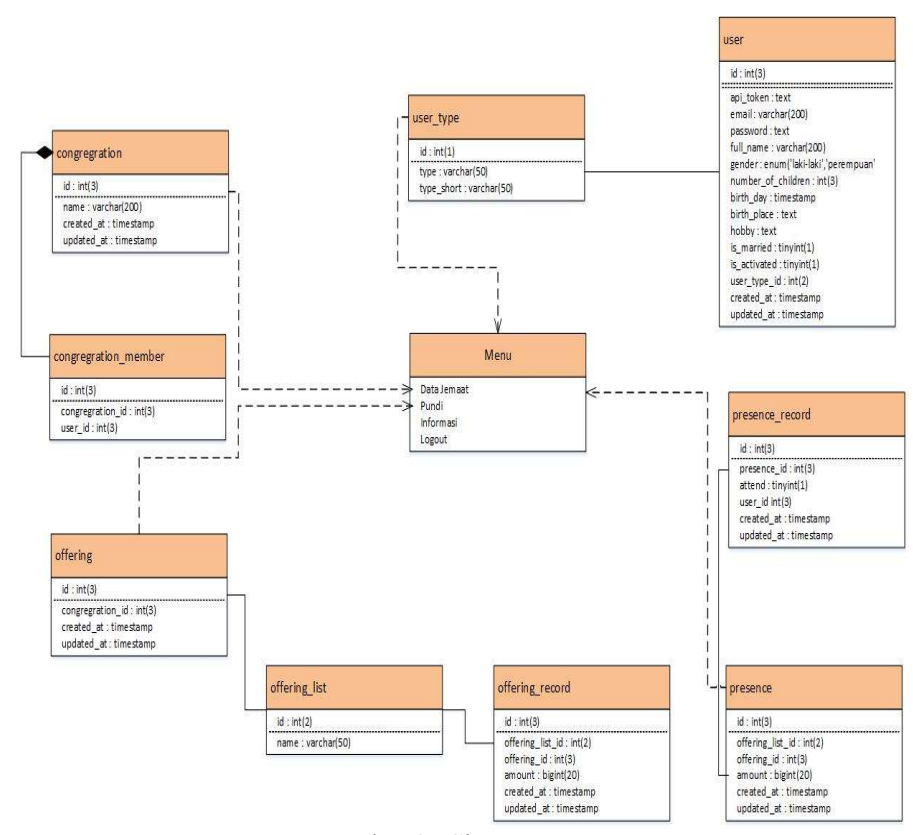

Gambar 3. Class Diagram

\section{Fase Desain Modeling}

Pada fase desain modeling aplikasi absensi jemaat dikembangkan berdasarkan analisis yang dilakukan pada fase analisis modeling sebelumnya. Pada tahapan analisis dan desain modeling mengalami perulangan bertujuan untuk medapatkan hasil perancangan sistem yang benar-benar memenuhi kebutuhan. Hasil dari fase ini adalah basis data, antarmuka dan spesifikasi desain. Use case pada android app, dimana user dapat melakukan proses absensi dan pelaporan persembahan dengan menginput data. Data hasil inputan user ini akan secara otomatis tersimpan ke dalam database sedangkan untuk melihat data, aplikasi akan secara langsung meminta data dari database untuk ditampilkan ke aplikasi. 


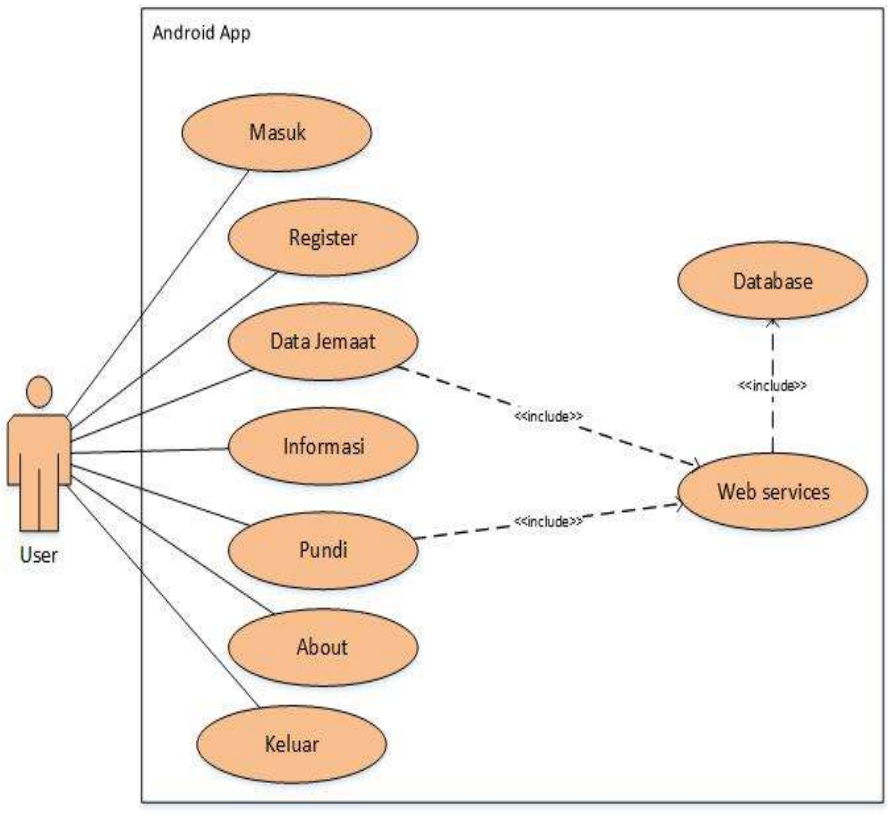

Gambar 4. Use Case Diagram client-side.

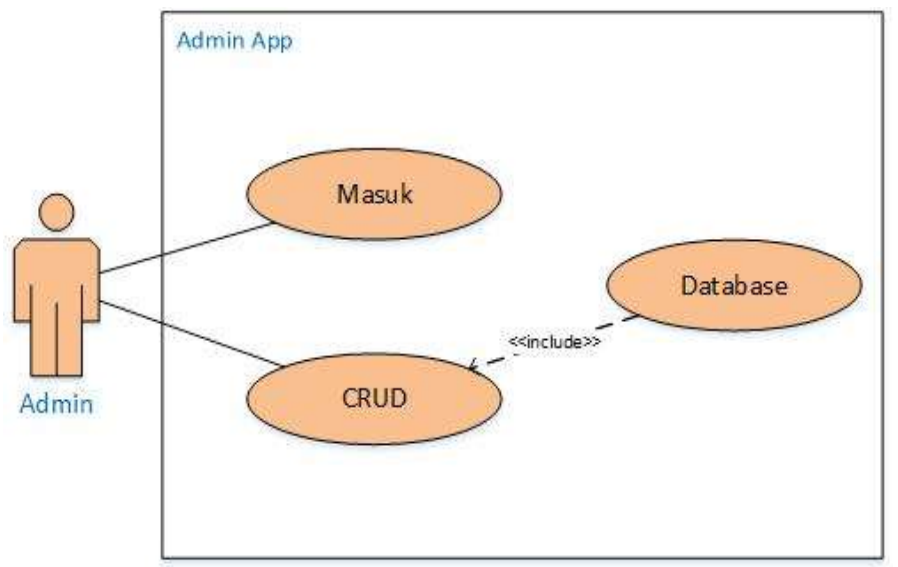

Gambar 5. Use Case Diagram server-side.

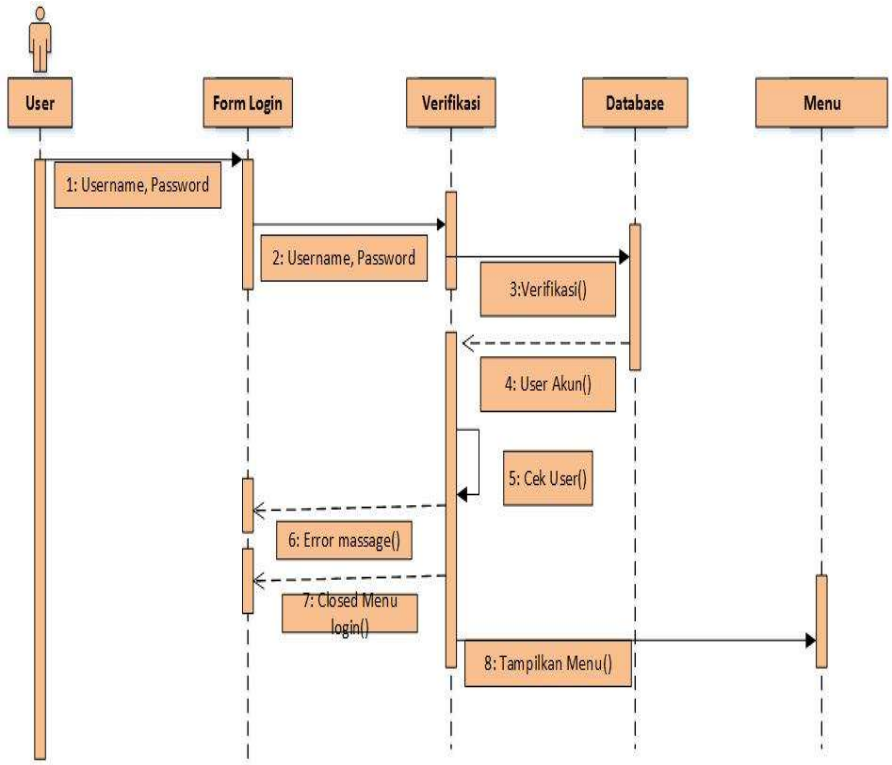

Gambar 6. Sequence Diagram Login

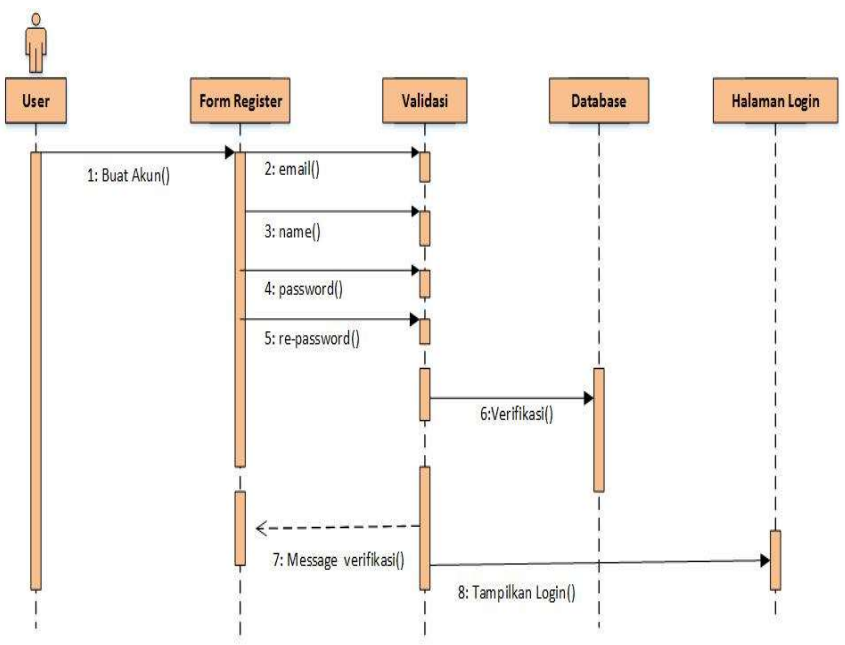

Gambar 7. Sequence Diagram Register

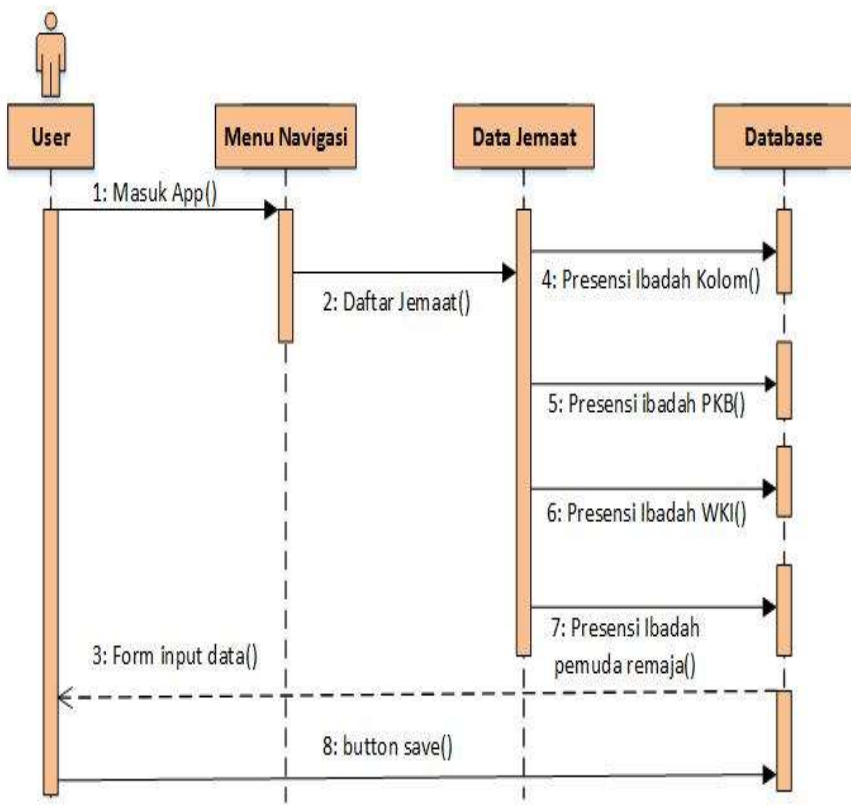

Gambar 8. Sequence Diagram Data Jemaat

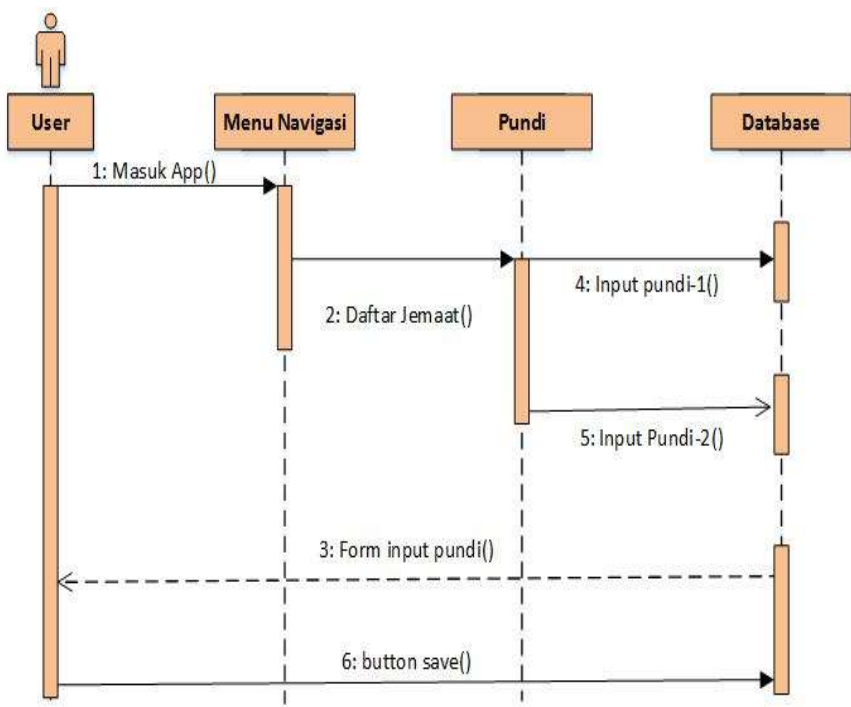

Gambar 9. Sequence Diagram Pundi 
1) Desain Antarmuka

Pada tahap selanjutnya adalah tahap merancang antarmuka untuk aplikasi yang akan dibangun, antarmuka ini bersifat sementara atau merupakan acuan kedepannya saat mengimplementasi antarmuka ini bisa saja terjadi perubahan sesuai kubutuhan. Antarmuka aplikasi dapat dilihat dari komponen-komponen penyusun antarmuka dan keterangan antarmuka. Gambar 10 menunjukkan langkah-langkah user (pelsus) melakukan absensi jemaat sesuai kolom yang bersangkutan dan Gambar 11 menunjukkan langkah-langkah user (pelsus) melakukan pelaporan persembahan sesuai dengan domisili kolom yang bersangkutan.

\begin{tabular}{|l|l|l|}
\hline \multicolumn{3}{|c|}{ Tampilan Data Jemaat (Presensi) } \\
\hline Komponen: \\
$\begin{array}{l}\text { - button 1: button navigasi } \\
\text { - button 2: approve } \\
\text { button 3: submenu } \\
\text { button_text : untuk melakukan } \\
\text { absensi jemaat sesuai yang dikepalai } \\
\text { user (pelsus) }\end{array}$ \\
\hline
\end{tabular}

Gambar 10. Desain Tampilan Data Jemaat

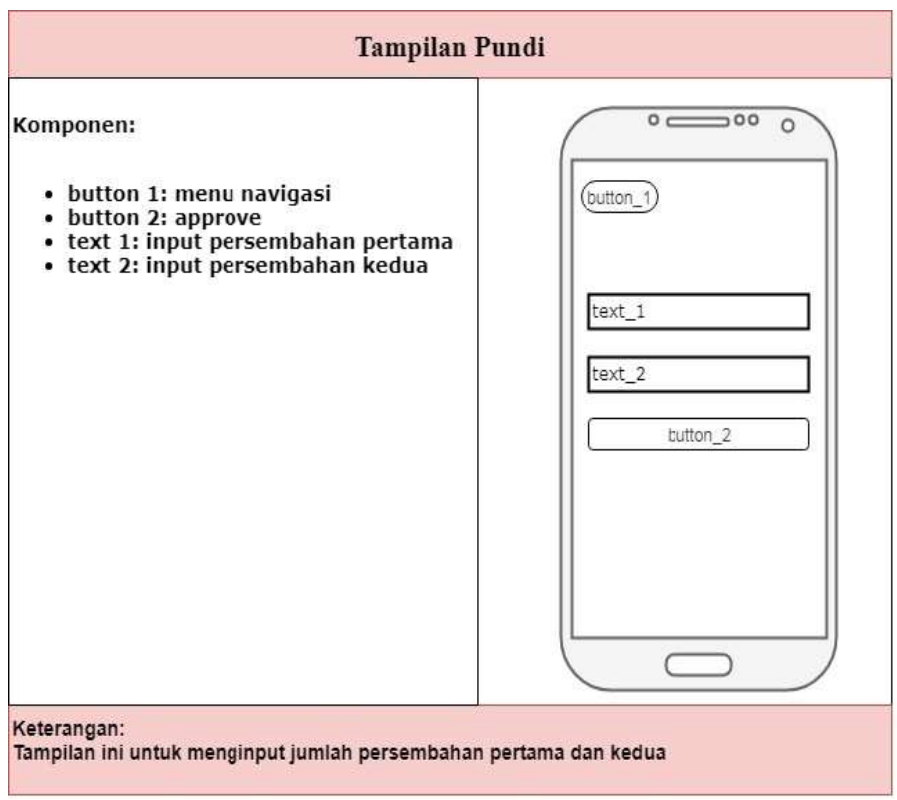

Gambar 11. Desain Tampilan Pundi

\section{HASIL DAN PEMBAHASAN}

\section{A. Implementasi Antarmuka}

Berikut ini adalah tampilan dari antarmuka aplikasi absensi jemaat berbasis android, pertama-tama user menjalankan aplikasi yang sudah diinstall pada perangkat android.
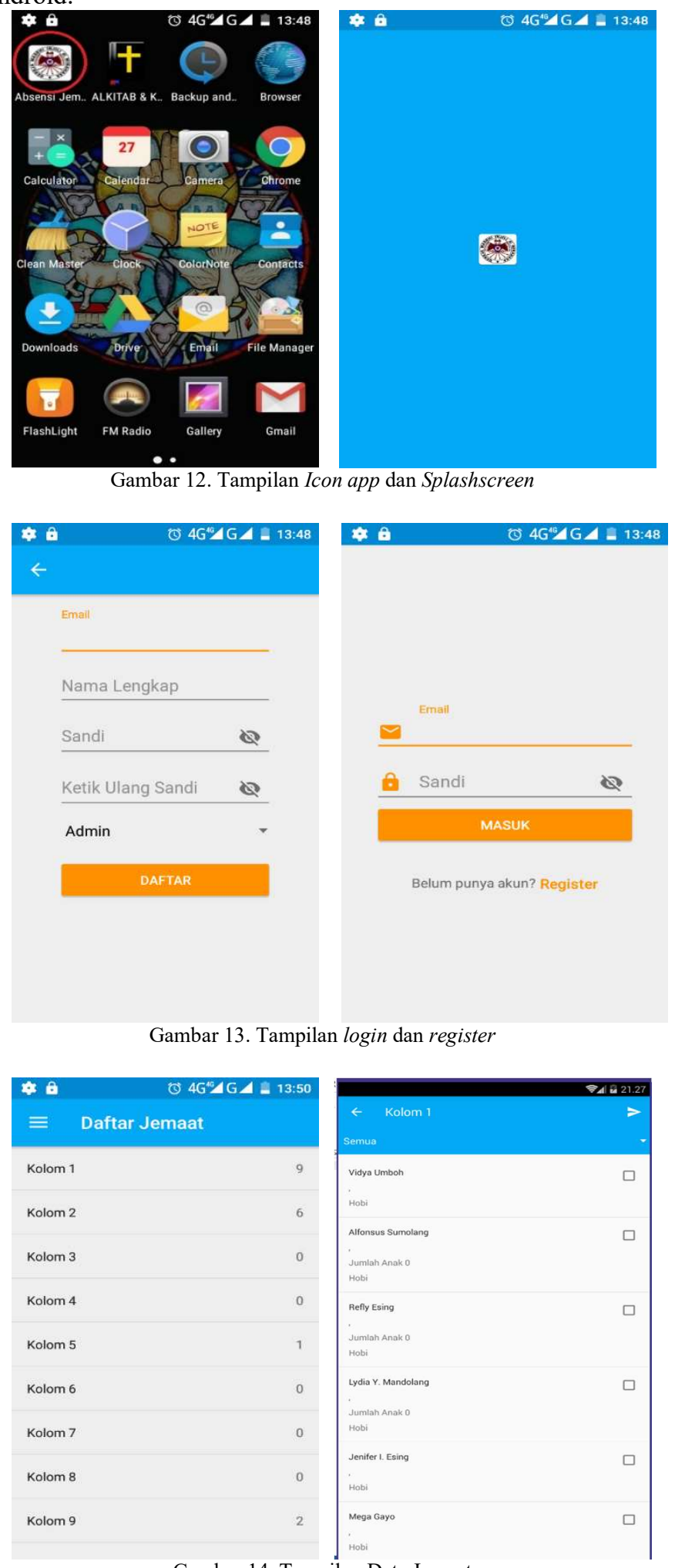

Gambar 14. Tampilan Data Jemaat 

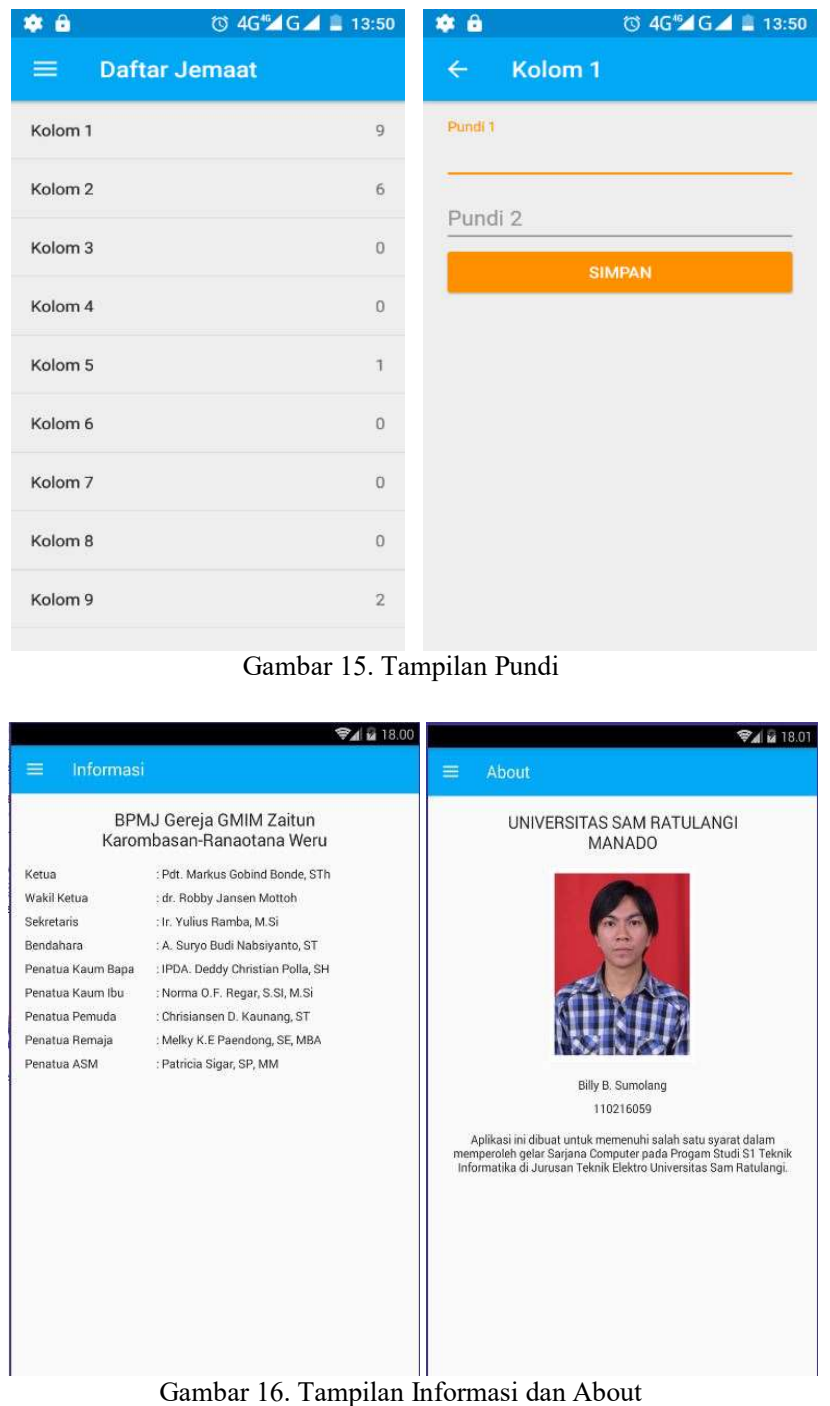

1) Gambar 12 menunjukkan tampilan aplikasi yang terinstal di perangkat android dan tampilan splashscreen.

2) Gambar 13 menunjukkan tampilan login dan register. Untuk menggunakan aplikasi ini user (pelsus) terlebih dahulu harus membuat akun dengan mengisi form yang ada pada aplikasi. Pada menu register ini terdapat pilihan apakah akun yang akan di daftarkan sebagai admin atau user (pelsus).

3) Gambar 14 menunjukkan user (pelsus) memilih fitur data jemaat maka akan muncul tampilan daftar jemaat dalam hal ini kolom. User (pelsus) melakukan presensi jemaat sesuai dengan domisili yang bersangkutan. Pada menu ini juga terdapat submenu pilihan kategorial ibadah pria kaum bapa, wanita kaum ibu dan pemuda remaja yang fungsinya sama dengan ibadah kolom yaitu untuk melakukan presensi dalam hal tingkat keaktifan anggota jemaat.

4) Gambar 15 menunjukkan pada saat user (pelsus) memilih fitur pundi maka akan muncul tampilan daftar jemaat dalam hal ini kolom. User (pelsus) melakukan penginputan jumlah persembahan di setiap akhir peribadatan sesuai dengan domisili user (pelsus) yang bersangkutan. Data yang di input berupa jumlah nominal persembahan di pundi satu dan pundi dua.
TABEL III. PENGUJIAN APLIKASI ANDROID

\begin{tabular}{|c|c|}
\hline No & Titik Pemeriksaan \\
\hline 1. & $\begin{array}{l}\text { Testing login. } \\
\text { Apakah form pengisian username dan password } \\
\text { berfungsi dengan baik? }\end{array}$ \\
\hline 2. & $\begin{array}{l}\text { Testing register. } \\
\text { Apakah akun yang dibuat dapat dibaca oleh sistem? }\end{array}$ \\
\hline 3. & $\begin{array}{l}\text { Testing halaman awal } \\
\text { Apakah tab navigasi berfungsi dengan baik? } \\
\text { Apakah button tab navigasi berfungsi dengan baik? }\end{array}$ \\
\hline 4. & $\begin{array}{l}\text { Testing halaman data jemaat } \\
\text { Apakah button text berfungsi dengan baik? } \\
\text { Apakah button text data jemaat berfungsi dengan baik? } \\
\text { Apakah Apakah button approve berfungsi? } \\
\text { Apakah Apakah button closed dapat berfungsi? }\end{array}$ \\
\hline 5. & $\begin{array}{l}\text { Testing halaman pundi } \\
\text { Apakah button text berfungsi dengan baik? } \\
\text { Apakah form pelaporan persembahan dapat berfungsi? } \\
\text { Apakah tombol approve dapat berfungsi untuk } \\
\text { mengirim pelaporan? } \\
\text { Apakah tombol closed pada menu pundi berfungsi? }\end{array}$ \\
\hline 6. & $\begin{array}{l}\text { Testing halaman informasi } \\
\text { Apakah button informasi berfungsi? } \\
\text { Apakah button tab navigasi untuk kembali berfungsi? }\end{array}$ \\
\hline 7. & $\begin{array}{l}\text { Testing halaman about } \\
\text { Apakah button about berfungsi? } \\
\text { Apakah button tab navigasi untuk kembali berfungsi? }\end{array}$ \\
\hline
\end{tabular}

\section{B. Pengujian Black Box}

Pengujian pada aplikasi android meliputi login, register, fungsi presensi, fungsi input data persembahan, lihat informasi, about dan logout, dapat dilihat pada tabel 3 .

5) Gambar 16 menunjukkan tampilan pada saat user memilih fitur informasi, maka akan ditampilkan struktur kepengurusan badan pekerja majelis jemaat (BPMJ) gereja GMIM zaitun karombasan-ranotana weru dan menu about informasi dari perancang aplikasi absensi jemaat.

\section{PENUTUP}

\section{A. Kesimpulan}

Berdasarkan hasil pengujian sistem yang telah dilakukan untuk aplikasi absensi jemaat berbasis android maka dapat disimpulkan sebagai berikut:

1) Aplikasi Absensi Jemaat Berbasis Android dengan menggunakan metode Rapid Application Development (RAD) berhasil dibangun. Presensi anggota jemaat dapat di aplikasikan dengan menggunakan android yang dijalankan pada ponsel pintar pada setiap peribadatan di tingkat kolom.

2) Pelaporan persembahan dapat di implementasikan dengan menggunakan android yang dijalankan pada ponsel pintar pada setiap peribadatan di tingkat kolom.

3) Aplikasi dapat berjalan dengan menggunakan koneksi internet. 
B. Saran

Berdasarkan hasil penelitian dan kesimpulan mengenai Aplikasi Absensi Jemaat Berbasis Android ini maka diajukan saran sebagai berikut:

1) Aplikasi ini dapat dikembangkan lebih informatif dan menarik dari segi tampilan bagi yang akan mengembangkannya.

2) Aplikasi ini masih bisa dikembangkan lagi terutama pada sisi admin dapat di buatkan web aplikasi (server side) agar mudah dioperasikan oleh admin dalam hal update data.

3) Menambahakan fitur tambahan cetak, sehingga pelaporan data dapat dicetak.

\section{KUTIPAN}

[1] Abdul Kadir 2003, Perangcangan Sistem Informasi, Andi Jogjakarta

[2] Al-Husain, 2017. Perancangan Sistem Absensi Online Menggunakan Android Guna Mempercepat Proses Kehadiran Karyawan Pada PT. Sintech Berkah Abadi. Technomedia Journal Vol.1 No.2, Tangerang.

[3] Kasenda Lorenzo M, Sentinuwo Steven, Tulenan Virginia (2016), Sistem Monitoring Kognitif, Afektif dan Psikomotorik Siswa Berbasis Android. Manado: e-journal unsrat 2016.

[4] Safaat, Nazruddin . 2012. Pemrograman Aplikasi Mobile Smartphone Dan Tablet PC Berbasis Android, Informatika, Bandung.

[5] Tangkudung Evert, Najoan Meicsy, Mamahit Dringhuzen (2018). Aplikasi Tata Cara Ibadah Berbasis Android. Manado: e-journal unsrat 2018.

[6] Pressman, R.S. 2010. Rekayasa Perangkat Lunak buku 1. Edisi 7, terjemahan Tim Penerjemah Andi, Yogyakarta

[7] Noertjahyana, A. 2002. Studi Analisis Rapid Application Development Sebagai Salah Satu Alternatif Metode Pengembangan Perangkat Lunak. Jurnal Informatika, Vol. 3, No.2.

[8] Mandagi, R.J.M. dkk. 2006. Panduan Penulisan KTIS. Tim Penyusun Panduan Penulisan KTIS Fakultas Teknik Unsrat, Manado.

\section{SEKILAS TENTANG PENULIS}

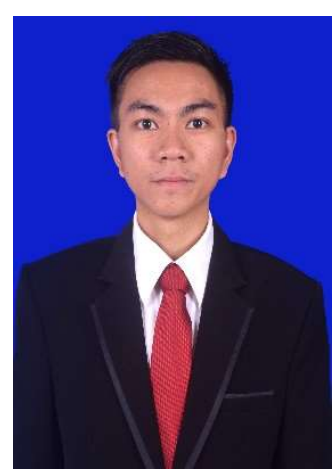

Sekilas dari penulis dengan nama lengkap Billy Brayen Sumolang, lahir di Manado 24 Januari 1993, Provinsi Sulawesi Utara. Anak pertama dari dua bersaudara. Dengan latar blakang pendidikan Sekolah Dasar GMIM 31 Manado, kemudian Melanjutkan ke Sekolah Menengah Pertama Negeri SMP Negeri 4 Manado, kemudian melanjutkan ke Sekolah Menengah SMK Negeri 1 Manado. Setelah lulus tahun 2011 melanjutkan ke Perguruan Tinggi di Universitas Sam Ratulangi Manado dengan mengambil Jurusan Teknik Elektro Program Studi Informatika. Pada tahun 2018 bulan maret, penulis membuat Skripsi sebagai salah satu syarat Sarjana (S1) dengan penelitian berjudul Aplikasi Absensi Jemaat Berbasis Android yang di bimbing oleh dua dosen pembimbing yaitu Dr.Eng. Steven R. Sentinuwo, ST., MTI dan Xaverius B.N Najoan, ST., MT sehingga pada tanggal 23 Agustus 2018 penulis resmi lulus di Teknik Informatika Universitas Sam Ratulangi Manado dan menyandang gelar Sarjana Komputer dengan predikat Memuaskan. 